\title{
A Simple Choice Model for Boundedly Rational Agents
}

\author{
Kemal YILDIZ ${ }^{1}$
}

\section{Abstract}

We analyze a restricted pro-con random choice model of Dogan and Yildiz (2018) in which there are only two observable orderings relevant for choice such as price and quality. An agent is endowed with two orderings that both serve as pro-orderings and con-orderings. For each choice set, if an alternative is the top-ranked (bottom-ranked) by one of these orderings, then this is a pro (con) for choosing that alternative. Each pro or con item has a weight reflecting its salience. Each alternative is chosen with a probability proportional to the total weight of its pros and cons. In our analysis, we provide a set of choice axioms, which guarantee that the observed choices can be generated via a pro-con random choice model with respect to two given observable orderings. A notable aspect of this characterization is that the associated axioms discipline the choice behavior when choice sets present attraction effect scenarios. This indicates the tight connection between the model and the attraction effect phenomena.

Key Words: Choice function, random choice, attraction effect

\section{Kısmi Rasyonel Bireyler İçin Basit Bir Seçim Modeli}

\section{$\ddot{O ̈}_{z}$}

Doğan ve Yıldız’n (2018) lehde veya aleyhte olasıllksal seçim modelinin, fiyat ve kalite gibi, sadece iki tane ve gözlemlenebilir sıralama olduğu duruma kısıtlanmış halini analiz ediyoruz. Lehde veya aleyhte kullanılabilir iki gözlemlenebilir sıralamaya sahip bir birey düşünelim. Her seçim kümesi için bir alternatif eğer bir sıralamanın en tepesinde (en altında) yer alıyorsa, bu onun seçilmesi için lehinedir (aleyhinedir). Lehde ve aleyhde olan her bir durumun etkisini gösteren bir ağırlığ vardır. Her bir alternatif lehindeki ve aleyhindeki sıralamaların ağırlıkları toplamıla orantısal olasılıkla seçilmektedir. Analizimizde, bireyin gözlemlenen seçimlerinin verili iki sıralama için lehde veya aleyhte olasılıksal seçim modeliyle tutarlı olmasını garanti eden seçim aksiyomlarını buluyoruz. Bu karakterizasyonun göze çarpan yönlerinden bir tanesi ilgili aksiyomların seçim kümelerinin cąibe etkisi senaryosu sergilediği durumlardaki seçim davranışını disipline sokmasıdır. Bu durum mevcut modelle cazibe etkisi kavramı arasındaki kuvvetli ilişkiyi ortaya koymaktadır.

Anabtar Kelimeler: Seçim fonksiyonu, Olasılıksal seçim, Cazibe etkisi

Atıf İçin / Please Cite As:

Yıldız, K. (2021). A simple choice model for boundedly rational agents. Manas Sosyal Araştrmalar Dergisi, 10(4), 2218-2225.

Geliş Tarihi / Received Date: 13.08.2020

Kabul Tarihi / Accepted Date: 06.08.2021

\footnotetext{
${ }^{1}$ Dr. Öğr. Üyesi - Bilkent Üniversitesi İktisat Bölümü, kemal.yıldız@bilkent.edu.tr
}

(D) ORCID: 0000-0003-4352-3197 


\section{Introduction}

In 1772, Joseph Priestley wrote a letter to Benjamin Franklin asking for Franklin's advice on a decision he was trying to make. Franklin wrote back indicating that he could not tell him what to do, but he could tell him how to make his decision, and suggested his prudential algebra. Here we present Franklin's (1887) choice procedure in his own words.

"To get over this, my Way is, to divide half a Sheet of Paper by a Line into two Columns, writing over the one Pro, and over the other Con. I endeavour to estimate their respective Weights; and where I find two, one on each side, that seem equal, I strike them both out: If I find a Reason pro equal to some two Reasons con, I strike out the three. If I judge some two Reasons con equal to some three Reasons pro, I strike out the five; and thus proceeding I find at length where the Ballance lies. And tho' the Weight of Reasons cannot be taken with the Precision of Algebraic Quantities, yet when each is thus considered separately and comparatively, and the whole lies before me, I think I can judge better, and am less likely to take a rash Step; and in fact I have found great Advantage from this kind of Equation, in what may be called Moral or Prudential Algebra."

Choice models most commonly used in economics are based on maximization of preferences. An alternative mode of choice, which is common is also commonly used for the analysis of 'case studies' in business and law schools, is the less formal reason-based analysis (Shafir et al.(1993)). To conduct reasonbased analysis, in the vein of Franklin's prudential algebra, first, various arguments that support or oppose an alternative are identified, then the balance of these arguments determines the choice. Dogan and Yildiz (2018) formulate and analyze the pro-con choice model that connects these two approaches by presenting a reason-based choice model, in which the 'reasons' are formed by using a preference-based language. In this paper, we analyze a restricted pro-con random choice model of Dogan and Yildiz (2018) in which there are only two observable orderings relevant for choice such as price and quality and relates to the well known attraction effect phenomena in marketing literature.

We conduct our analysis in the stochastic choice setup. In this setup, an agent's repeated choices or a group's choices are summarized by a random choice function (RCF) $p$, which assigns to each choice set $S$, a probability measure over $S$. For each choice set $S$ and alternative $x$, we denote by $p(x, S)$ the probability that alternative $x$ is chosen from choice set $S$.

As introduced by Dogan and Yildiz (2018), a random pro-con rational model (RpcM) is a triplet $\langle>, \triangleright, \lambda\rangle$, where $>$ and $\triangleright$ stand for the sets of pro-preferences and con-preferences, as before. The weight function $\lambda$ assigns to each pro-preference $>_{i} \in>$ and con-preference $\triangleright_{i} \in \triangleright$, a value in the $(0,1]$ interval, which we interpret as a measure of the salience of each preference. In line with the experimental findings of Shafir (1993) indicating that the weight assigned to the pros is more than the weight assigned to the cons, we require that the difference between the weighted sum of pro-preferences and con-preferences is unity. Thus, the model is testable by using random choice data. The total weight of an alternative in a choice set is obtained by adding the total weight of the pro-orderings at which it is top-ranked and the total weight of the con-orderings at which it is bottom-ranked. To make a choice from each choice set, a pro-con rational agent considers the alternatives with a positive total weight, and chooses each alternative from this consideration set with a probability proportional to its total weight.

Dogan and Yildiz (2018) show that every nuance of the rich human choice behavior can be captured via this model. That is, every random choice function is pro-con rational. Given this all goes result, a natural concern is the number of orderings used in the pro-con choice model. In several choice problems the number of orderings that are relevant for the problem can be limited. For example, in the classical attraction effect scenario ${ }^{2}$ it seems that there are only two relevant criteria for choice, such as price and quantity. The pro- and con-preferences used in our Example 1, which is borrowed from Dogan and Yildiz (2018), correspond to these criteria. As a result, the choice probability of an alternative may increase when a decoy is added, since this alternative may no longer be the worst one according to a relevant criterion.

In this paper, we focus on a particular choice problem in which there are only two observable orderings $\left(>_{1},>_{2}\right)$ that are relevant for choice, such as price and quality. This provides a generalization of

\footnotetext{
2 Payne and Puto (1982) and Huber and Puto (1983). Following their work, evidence for the attraction effect has been observed in a wide variety of settings. For a list of these results, consult (Rieskamp et al. (2006)).
} 
Example 1, which presents an attraction effect scenario. In our analysis, we provide a set of choice axioms, which guarantee that the observed choices can be generated via an RpcM in which the propreferences and the con-preferences are obtained from the given preference pair. A notable aspect of this characterization is that attraction effect type of choice behavior is the content of some of the axioms, such as the attraction axiom, which indicates the tight connection between the model and the attraction effect phenomena. Moreover, we believe that our results and constructions in their proofs paves the way for empirical identification of the model from observable choices. In a related paper, Yildiz (2020) presents a version of this model in which the orderings are unobservable and derived from the choice data. ${ }^{3}$

\section{Method}

To introduce the model, first, we present the following example borrowed from Dogan and Yildiz (2018). This example illustrates that when we introduce an asymmetrically dominated alternative, the choice probability of the dominating alternative may go up. This choice behavior, known as the attraction effect, is incompatible with any random utility model.

Example 1 (Attraction Effect): Suppose there are three alternatives $\mathrm{x}, \mathrm{y}, \mathrm{z}$, where $\mathrm{x}$ and $\mathrm{y}$ are two competing alternatives such that none clearly dominates the other. That is, $\mathrm{x}$ is cheaper than $\mathrm{y}\left(\mathrm{x}>_{1} \mathrm{y}\right)$, but $\mathrm{y}$ has a higher quality than $\mathrm{x}\left(\mathrm{y}>_{2} \mathrm{x}\right)$. Suppose $\mathrm{z}$ is another alternative that is dominated by $\mathrm{x}$ both in terms of price and quality but not by $\mathrm{y}$, since $\mathrm{z}$ is cheaper than $\mathrm{y}$. That is, $\mathrm{z}$ is a 'decoy' for $\mathrm{x}$ when $\mathrm{y}$ is available.

\begin{tabular}{|l|l|}
\hline \multicolumn{2}{|l|}{} \\
\hline$(1 / 2)$ & $(1 / 2)$ \\
\hline$>_{1}$ & $>_{2}$ \\
\hline $\mathrm{x}$ & $\mathrm{y}$ \\
\hline $\mathrm{z}$ & $\mathrm{x}$ \\
\hline $\mathrm{y}$ & $\mathrm{z}$ \\
\hline$(1 / 4)$ & $(1 / 4)$ \\
\hline
\end{tabular}

Now, since in terms of both price and quality, $\mathrm{x}$ is better than $\mathrm{z}$, we get $\mathrm{z}$ is never chosen in a binary comparison with $\mathrm{x}$ $(p(z,\{x, z\})=0)$. Since $x$ and $y$ fail to dominate each other, and $y$ fails to dominate $\mathrm{z}$, we get each of them are chosen evenly in a binary comparison $(\mathrm{p}(\mathrm{x},\{\mathrm{x}, \mathrm{y}\})=1 / 2)$. Note that when only $\mathrm{x}$ and $\mathrm{y}$ are available, since $\mathrm{x}$ has the least quality ( $>_{2}$-worst alternative), $\mathrm{x}$ has a 'con'. However, when the decoy $\mathrm{z}$ is added to the choice set, then this is no longer the case since $\mathrm{z}$ has the least quality. Thus, we can expect an increase in the choice probability of $\mathrm{x}$, $(p(x,\{x, y, z\})=2 / 3)$. That is, availability of decoy $z$ increases the choice probability of $\mathrm{x}$. Thus, the proposed rule presents an attraction effect scenario. The pro-con model with respect to the above $\left(>_{1},>_{2}\right)$ together with the associated weights for pros and cons generate this choice behavior.

One can imagine several similar choice scenarios, in which there are two criteria that are relevant for choice are observable. Here, we analyze the pro-con random choice model specified for a given pair of preferences, which generalizes this example. Next, we formally introduce the model.

Given a nonempty finite alternative set $X$, any nonempty subset $S$ is called a choice set. Let $\Omega$ denote the collection of all choice sets. A random choice function (RCF) $\mathrm{p}$ is a mapping that assigns each choice set $S \in \Omega$, a probability measure over $S$. For each $S \in \Omega$ and $x \in S$, we denote by $\mathrm{p}(\mathrm{x}, \mathrm{S})$ the probability that alternative $\mathrm{x}$ is chosen from choice set $\mathrm{S}$. A preference, denoted generically by $>_{i}$ is a complete, transitive, and antisymmetric binary relation on $\mathrm{X}$.

We focus on a particular choice problem in which there are only two observable orderings $\left(>_{1},>_{2}\right)$ that are relevant for choice, such as price and quality. This provides a generalization of Example 1, which presents an attraction effect scenario.

Given a pair of preferences $\left(>_{1},>_{2}\right)$, for each choice set $S$ and alternative $x \in S$, if $x$ is the $>_{i}$-best alternative in $\mathrm{S}$ for some $\mathrm{i} \in\{1,2\}$, then we interpret this as a 'pro' for choosing $\mathrm{x}$ from $\mathrm{S}$. On the other hand, if $\mathrm{x}$ is the $>_{\mathrm{i}}$-worst alternative in $\mathrm{S}$ for some $\mathrm{i} \in\{1,2\}$, then we interpret this as a 'con' for choosing $\mathrm{x}$ from S. Formally, let $\operatorname{Pros}(\mathrm{x}, \mathrm{S})=\left\{\mathrm{i} \in\{1,2\}: \mathrm{x}=\max \left(\mathrm{S},>_{\mathrm{i}}\right)\right\}$ and $\operatorname{Cons}(\mathrm{x}, \mathrm{S})=\{\mathrm{i} \in\{1,2\}: \mathrm{x}=$ $\left.\min \left(\mathrm{S},>_{\mathrm{i}}\right)\right\}$.

\footnotetext{
${ }^{3}$ The author also orally presented the content of this related paper in the $5^{\text {th }}$ International Conference on Multidisciplinary Sciences (icomus) and the abstract appeared in the abstract book of this conference, Yildiz (2020).
} 
A weight function, denoted by $\lambda$ is such that for each $i \in\{1,2\}$, we have $\lambda_{i}^{+} \in(0,1]$ and $\lambda_{i}^{-} \in(0,1]$, and the difference between the weighted sum of pros and cons is one, i.e. $\lambda_{1}^{+}+\lambda_{2}^{+}-\lambda_{1}^{-}-\lambda_{2}^{-}=1$. The weight function $\lambda$ acts like a probability measure over the set of preferences that can assign negative values. We interpret the weight assigned to each pro or con as a measure of its salience.

Next, for each $S \in \Omega$ and $x \in S$, define the score $\lambda(x, S)=\sum_{i \in \operatorname{Pros}(x, S)} \lambda_{i}^{+}-\sum_{i \in \operatorname{Cons}(x, S)} \lambda_{i}^{-}$, and $\mathrm{S}^{+}=\{\mathrm{x} \in \mathrm{S}: \lambda(\mathrm{x}, \mathrm{S})>0\}$. Next, we formally define when an RCF is pro-con rational with respect to $\left(>_{1},>_{2}\right)$.

Definition: An RCF p is pro-con rational with respect to $\left(>_{1},>_{2}\right)$ if there is a weight function $\lambda$ such that for each choice set $S \in \Omega$ and $\mathrm{x} \in \mathrm{S}$,

$$
p(x, S)= \begin{cases}\frac{\lambda(x, S)}{\sum_{\left\{y \in S^{+}\right\}} \lambda(y, S)} & \text { if } \lambda(x, S)>0 \\ 0 & \text { if } \lambda(x, S) \leq 0\end{cases}
$$

That is, to make a choice from each choice set $S$ according to a pro-con choice model with respect to some $\left(>_{1},>_{2}\right)$, the agent considers the alternatives with a positive $\lambda(x, S)$ score, and chooses each alternative from this consideration set with a probability proportional to its weight.

This model is a special case of random pro-con rational choice due to Dogan and Yildiz (2018): An RCF $p$ is pro-con rational with respect to $\left.\left(>_{1},\right\rangle_{2}\right)$ means that there is a RpcM $\langle>, \nabla, \lambda\rangle$ that represents $\mathrm{p}$, in which both the pro-preferences and the con-preferences are the given $\left(>_{1},>_{2}\right)$.

\section{Results}

Our first axiom, domination, requires that if an alternative dominates another, in the sense that the former is better than the latter in both orderings, then the dominated one is never chosen when both are available. Formally, for each $x, y \in X, x$ dominates $y$, denoted by $x>>y$ if $x>_{1} y$ and $x>_{2} y$.

Domination: For each $S \in \Omega$ and $x, y \in S$, if $x>>y$, then $p(y, S)=0$.

Our second axiom, attraction, requires that adding an alternative dominated by another one should not decrease the choice probability of the dominating alternative.

Attraction: For each $S \in \Omega$ and $x, z \in X$, if $x>>z$, then $p(x, S \cup\{z\}) \geq p(x, S)$.

As in an attraction effect scenario, for each $x, y, z \in X$, if neither $y$ dominates $x$ or $z$, nor $x$ or $z$ dominates $y$, but $x$ dominates $z$, then $\boldsymbol{z}$ is a decoy for $\boldsymbol{x}$ when $\boldsymbol{y}$ is available. It directly follows from attraction that if $z$ is a decoy for $x$ when $y$ is available, then $p(x,\{x, y, z\}) \geq p(x,\{x, y\})$.

Our third axiom, best-worst nentrality, requires that if two choice sets are similar to each other in the sense that the $\left(>_{1},>_{2}\right)$-best alternatives in $S$ can be renamed as to obtain the configuration of the $\left(>_{1},>_{2}\right)$-best alternatives in $S^{\prime}$ in the best and worst positions, then the choice probabilities should be preserved under this renaming. Formally, a choice set $S$ is best-worst isomorphic to another one $S^{\prime}$, denoted by $S \sim^{\pi} S^{\prime}$, if there is a one-to-one mapping $\pi$ between the $\left(>_{1},>_{2}\right)$-best alternatives in $S$ and the $\left(>_{1},>_{2}\right)$-best alternatives $S^{\prime}$ such that for each $i, j \in\{1,2\}$ and $x \in \max \left(S,>_{i}\right)$,

1. $x=\max \left(S,>_{i}\right)$ if and only if $\pi(x)=\max \left(S^{\prime},>_{i}\right)$, and

2. $x=\min \left(S,>_{j}\right)$ if and only if $\pi(x)=\min \left(S^{\prime},>_{j}\right)$.

Best-worst neutrality: For each $S, S^{\prime} \in \Omega$, if $S \sim^{\pi} S^{\prime}$, then for each $x \in \max \left(S,>_{i}\right)$ where $i \in$ $\{1,2\}, p(x, S)=p\left(\pi(x), S^{\prime}\right)$.

To introduce our last axiom, we first define the choice likelihood of $\boldsymbol{x}$ from $\boldsymbol{S}$ as the ratio of the probability that alternative $x$ is chosen from choice set $S$ to the probability that any other alternative is chosen from $S$, that is, $L(x, S)=\frac{p(x, S)}{1-p(x, S)}$. Next, we present and interpret our last axiom.

Attraction gain equivalence: For each $x, y, z, w \in X$, if $z$ is a decoy for $x$ when $y$ is available and $w$ is a decoy for $y$ when $x$ is available, then 


$$
\frac{L(x,\{x, y, z\})}{L(y,\{x, y, w\})}=\frac{L(x,\{x, y, z, w\})}{L(y,\{x, y\})} .
$$

To get an intuition for attraction gain independence, note that the two choice likelihood ratios $\frac{L(x,\{x, y, z\})}{L(y,\{x, y, w\})}$ and $\frac{L(x,\{x, y, z, w\})}{L(y,\{x, y\})}$ can be interpreted as measures of the attraction gain of $x$ relative to that of $y$. In that, the former is the ratio of the choice likelihood of $x$ to $y$ when each alternative's decoy is added separately; the latter is the ratio of the choice likelihood of $x$ in the availability of both decoys, to the choice likelihood of $y$ in the absence of any decoy. Attraction gain equivalence requires these two plausible measures of relative attraction gain be equal. Next, we state our characterization result.

Theorem 1 For a given $\left(>_{1},>_{2}\right)$, an RCF $p$ is pro-con rational w.r.t. $\left(>_{1},>_{2}\right)$ if and only if $p$ satisfies domination, attraction, best-worst neutrality, and attraction gain equivalence.

Proof. We leave it to the reader to show that if an RCF $p$ is pro-con choice w.r.t. a given $\left(>_{1},>_{2}\right)$, then $p$ satisfies our axioms. Conversely, let $p$ be an RCF that satisfies our axioms. Before constructing the weight function, let us make a key observation. Consider the five types of configurations below that are obtained by restricting a given $\left(>_{1},>_{2}\right)$ to a given choice set.

To clarify the terminology, we say that type $i$ configuration is observed if there is a choice set such that if we restrict the given $\left(>_{1},>_{2}\right)$ to this set, then we obtain a configuration as in type $i$. For example, type 2 configuration is observed if there exist $x, y, z \in X$ such that $x>>z$ and $y>>z$, but neither $x>>y$ nor $y>>x$. For each choice set $S \in X$, if we obtain the configuration type $i$ when $\left(>_{1},>_{2}\right)$ are restricted to $S$, then $S$ is called a type $\boldsymbol{i}$ choice set.

First, it is easy to note that domination implies that for each type $i$ choice set $S_{i}$, if $x=\max \left(S_{i},>_{1}\right)$ and $y=\max \left(S_{i},>_{2}\right)$, then $p\left(x, S_{i}\right)+p\left(y, S_{i}\right)=1$. Next, note that for each $S \in X$, there exists a type $i$ choice set $S_{i}$, for $i \in\{0, \ldots, 4\}$, such that $S$ is isomorphic to $S_{i}$. Then, it follows from best-worst neutrality that if we construct the weights as to obtain $p\left(\left(\max \left(S_{i}\right),>\right)\right)$, then by using the same weights we obtain

\begin{tabular}{|cccccccccc|}
\hline Type 0 & & Type 1 & Type 2 & & Type 3 & \multicolumn{2}{c|}{ Type 4 } \\
\hline$>_{1}$ & $>_{2}$ & $>_{1}$ & $>_{2}$ & $>_{1}$ & $>_{2}$ & $>_{1}$ & $>_{2}$ & $>_{1}$ & $>_{2}$ \\
$x$ & $x$ & $x$ & $y$ & $x$ & $y$ & $x$ & $y$ & $x$ & $y$ \\
$y$ & $y$ & $y$ & $x$ & $y$ & $x$ & $w$ & $x$ & $y$ & $z$ \\
& & & & $z$ & $z$ & $y$ & $w$ & $z$ & $x$ \\
& & & & & & & & &
\end{tabular}

$p((\max (S),>))$. This together with the first observation imply that to render a pro-con choice representation for $p$ with respect to $\left(>_{1},>_{2}\right)$, it is sufficient to construct the weights as to generate the choice probabilities for these five types of choice sets.

Now, we need to construct four weights, namely $\lambda_{1}, \lambda_{2}, \lambda_{3}$, and $\lambda_{4}$, as to render a pro-con choice representation of $p$ w.r.t. $\left(>_{1},>_{2}\right)$. Note that depending on $X$ and $\left(>_{1},>_{2}\right)$, we may not observe each configuration type. In what follows, we analyze the problem case by case. First let us make some primitive observations to rule out the trivial cases. If $X=\{x, y\}$, then the construction is trivial, so we assume that $X$ has at least three alternatives. We assume that there exist distinct $x, y \in X$ with $x>_{1} y$, and $y>_{2} x$. If not, then $>_{1}=>_{2}$, and domination implies that for each $S \in \Omega, p\left(\max \left(S,>_{1}\right)\right)=1$. So, we can choose the weights in any arbitrary way. For each $S \in \Omega$ that is isomorphic to a type 0 choice set, the alternative that is $>_{1^{-}}$and $>_{2}$-best is chosen with probability one, irrespective of the weight function. Therefore, we disregard these choice sets in the following reasoning.

Case 1: Suppose there exist $x, y, z, w \in X$ such that $z$ is a decoy for $y$ when $x$ is available and $w$ is a decoy for $x$ when $y$ is available. It follows that $x, y, z, w$ are all distinct. Now, first define $\lambda_{1}=$ $p(x,\{x, y, z, w\})$ and $\lambda_{2}=p(y,\{x, y, z, w\})$. Since $x>>w$ and $y>>z$, it follows from domination that $\lambda_{1}+\lambda_{2}=1$. Next, consider the set $\{x, y, z\}$, and define $\lambda_{4}=\frac{p(y,\{x, y, z\})-\lambda_{2}}{p(y,\{x, y, z\})}$. Since $x>>w$, attraction 
implies that $p\left(x,\{x, y, z, w\} \geq p\left(x,\{x, y, z\}\right.\right.$. This, together with our choice of $\lambda_{2}$, implies that $p(y,\{x, y, z\})-\lambda_{2} \geq 0$. Therefore, $\lambda_{4} \geq 0$, and we obtain that $p(y,\{x, y, z\})=\frac{\lambda_{2}}{1-\lambda_{4}}$, as desired. To define $\lambda_{3}$, consider the set $\{x, y, w\}$ and define $\lambda_{3}=\frac{p(x,\{x, y, w\})-\lambda_{1}}{p(x,\{x, y, w\})}$. Similarly, attraction implies that $\lambda_{3} \geq$ 0 , and we obtain that $p(x,\{x, y, w)\}=\frac{\lambda_{1}}{1-\lambda_{3}}$, as desired. Finally, consider the set $\{x, y\}$. It follows from attraction gain equivalence that if we substitute the defined weights for the choice likelihoods except $L(x,\{x, y\})$, then we obtain that $\frac{p(x,\{x, y\})}{p(y,\{x, y\})}=\frac{\lambda_{1}-\lambda_{4}}{\lambda_{2}-\lambda_{3}}$, as desired.

Case 2: Suppose for each distinct $x, y \in X$ there is no $z, w \in X$ such that $x>>w$ and $y>>z$. It follows that for each distinct $x, y \in X$ and $z, w \in X$, either $z$ is a decoy for $y$ when $x$ is available or $w$ is a decoy for $x$ when $y$ is available. Assume w.l.o.g. that $z$ is a decoy for $y$ when $x$ is available. Now, first define $\lambda_{1}=p(x,\{x, y, z\})$ and $\lambda_{2}=p(y,\{x, y, z\})$. If there exists an alternative $w$ that is a decoy for $x$ when $y$ is available, then define $\lambda_{3}$ as to satisfy $p(x,\{x, y, w\})=\frac{\lambda_{1}}{1-\lambda_{3}}$. For a given $\lambda_{1}$ and $\lambda_{2}$, there exists a unique such $\lambda_{3}$. Finally, define $\lambda_{4}$ as to satisfy $p(x,\{x, y\})=\frac{\lambda_{1}-\lambda_{4}}{\lambda_{2}-\lambda_{3}}$.

Case 3: Suppose that both case 1 and case 2 fail to hold. Since case 2 fails to hold, there exist distinct $x, y \in X$ and $z, w \in X$ such that $x>>w$ and $y>>z$. Since case 1 fails to hold, three scenarios can happen: (1) Both $x$ and $y$ dominate $z$ and $w$, (2) $z$ is a decoy for $y$ when $x$ is available, and $y>>w$, or (3) $w$ is a decoy for $x$ when $y$ is available, and $x>>$.

Suppose that scenario (1) holds, we follow a construction similar to that of case 2. First, define $\lambda_{1}=$ $p(x,\{x, y, z, w\})$ and $\lambda_{2}=p(y,\{x, y, z, w\})$. Then, since there is no alternative that is a decoy for another in the availability of a third one, we can freely define $\lambda_{3}$ and $\lambda_{4}$ to satisfy $p(x,\{x, y\})=\frac{\lambda_{1}-\lambda_{4}}{\lambda_{2}-\lambda_{3}}$.

Suppose that scenario (2) holds, then we follow a construction similar to that of case 1. First, define $\lambda_{1}=p(x,\{x, y, z, w\})$ and $\lambda_{2}=p(y,\{x, y, z, w\})$. Define $\lambda_{4}$ as to satisfy $p(y,\{x, y, z\})=\frac{\lambda_{2}}{1-\lambda_{4}}$. Next, since $w$ is not a decoy for $x$ when $y$ is available, we can define $\lambda_{3}$ as to satisfy $p(x,\{x, y\})=\frac{\lambda_{1}-\lambda_{4}}{\lambda_{2}-\lambda_{3}}$. Finally, for scenario (3), a symmetric construction works. Thus, for all possible cases, we can define a weight function $\lambda$ as to render a pro-con choice representation for $p$ with respect to $\left(>_{1},>_{2}\right)$.

\section{Discussion, Conclusion and Suggestions}

In our analysis, we provide a set of choice axioms, which guarantee that the observed choices can be generated via a dual pro-con random choice model. A notable aspect of this characterization is that the associated axioms discipline the choice behavior when choice sets present attraction effect scenarios. This indicates the tight connection between the model and the attraction effect phenomena.

The specific pro-con choice model analyzed in this section is related to the literature on dual-self models. Among these, De Clippel and Eliaz (2012) propose a deterministic choice model in which an agent seeks to reach a compromise between two inner selves that represent two attributes of the available alternatives. As we do in this section, they also assume that two orderings that represent the two inner selves are observable. They characterize a model of reason-based choice obtained as a result of a cooperative solution to the bargaining problem between the two selves, which accounts for both the deterministic formulations of the attraction and the compromise effects. Another related paper is Manzini and Mariotti (2018), who provide a characterization of the random utility model with two preferences. In here, we assume that the preferences are observed, and used not only on the pro-side, but also on the conside. Therefore, we end up in substantially different characterizations. In this vein, one question that we analyze in a follow-up study is whether we can identify pro-con choice by deriving $\left(>_{1},>_{2}\right)$ from agent's choices, which requires a different and more complicated technical approach. 
In writing the paper titled "A Simple Choice Model for Boundedly Rational Agents" we obeyed all ethical, scientific and referential rules and this study is not sent to any other place to be evaluated for publishing. Since the data set is used in this article, ethics committee approval is not required.

\section{References}

De Clippel, G. ve Eliaz, K. (2012). Reason-based choice: A bargaining rationale for the attraction and compromise effects. Theoretical Economics, 7(1), 125-162.

Dogan, S. ve Yildiz, K. (2018). Every choice function is pro-con rationalizable. Available at SSRN 3085542.

Franklin, B. (1887). The Complete Works of Benjamin Franklin: 1772-1775, volume 5. GP Putnam's Sons.

Huber, J. ve Puto, C. (1983). Market boundaries and product choice: Illustrating attraction and substitution effects. The Journal of Consumer Research, 10(1), 31-44.

Payne, J. W. ve Puto, C. (1982). Adding asymmetrically dominated alternatives: Violations of regularity and the similarity hypothesis. Journal of Consumer Research, 9(1), 90-98.

Manzini, P. ve Mariotti, M. (2018). Dual random utility maximisation. Journal of Economic Theory, 177, 162-182.

Rieskamp, J. ve Busemeyer, J. R. ve Mellers, B. A. (2006). Extending the bounds of rationality: evidence and theories of preferential choice. Journal of Economic Literature, 44(3), 631-661.

Shafir, E. (1993). Choosing versus rejecting: Why some options are both better and worse than others. Memory \& cognition, 21(4), 546-556.

Shafir, E., Simonson, I. ve Tversky, A. (1993). Reason-based choice. Cognition, 49(1), 11-36.

Yildiz, K. (2020). Dual pro-con Rationality. In the 5 th International Conference on Multidisciplinary Sciences (icomus) Abstracts Book, May 28-30, 2020, Turkey, ISBN: 978-605-80062-8-7.

\section{TÜRKÇE UZUN ÖZET}

1772'de Joseph Priestley, Benjamin Franklin'e, vermeye çalıştı̆ı bir karar hakkında Franklin'den tavsiye isteyen bir mektup yazdı. Franklin, ona ne yapması gerektiğini söyleyemediğini, ancak kararını nasıl vereceğini söyleyebildiğini belirten bir cevap yazdı ve ihtiyatlı cebirini önerdi. Burada Franklin'in (1887) seçim prosedürünü kendi sözlerini çevirerek sunuyoruz.

"Bunun üstesinden gelmek için benim yolum, bir kâğıdı bir çizgiyle iki sütuna bölerek birnin üzerine karar için leyhte maddeleri diğerin üzerine seçim için aleyhte olan maddeleri yazmaktır. Daha sonra her maddenin ağıllkklarını tahmin etmeye çalş̧ıorum. Ağrllkları eşit görünen her iki tarafta birer madde bulduğumda, ikisini de elerim. Eğer iki aleyhte maddeye eşit bir leyhte madde bulursam, üçünü elerim. Belirli iki aleyhte maddenin yaklaşık üç leyhte maddeye eşit olduğu yargısına varırsam, beşini elerim; ve böylece devam ederek dengenin nerede olduğunu uzun uzadiya buluyorum. Maddelerin önemi cebirsel miktarların kesinliği ile ele alınamaz belki, ancak her biri bu şekilde ayrı ayrı ve karşıaştırmalı olarak ele alındığında ve bütün önümde olduğunda, sanırım daha iyi yargılara varabilirim ve aceleci bir adım atmam daha az olasıdır; ve aslında bu tür ahlaki veya ihtiyati cebir olarak adlandırllabilecek bir karar verme yönteminde büyük fayda buldum."

Ekonomide en yaygın olarak kullanılan seçim modelleri, tercihlerin maksimizasyonuna dayanmaktadır. İşletme ve hukuk bölümlerinde 'vaka çalışmalarının' analizi için de yaygın olarak kullanılan alternatif bir seçim modu, daha az resmi nedene dayalı analizdir.

Mevcut çalışmada Dogan ve Yildiz (2018)'in lehde veya aleyhte olasılıksal seçim modelinin, fiyat ve kalite gibi, sadece iki tane ve gözlemlenebilir sıralama olduğu duruma kısıtlanmış halini analiz ediyoruz. Lehde veya aleyhte kullanılabilir iki gözlemlenebilir sıralamaya sahip bir birey düşünelim. Her seçim kümesi için bir alternatif eğer bir sıralamanın en tepesinde (en altında) yer alıyorsa, bu onun seçilmesi için lehinedir (aleyhinedir). Lehde ve aleyhde olan her bir durumun etkisini gösteren bir ağırllğı vardır. Herbir alternatif lehindeki ve aleyhindeki sıralamaların ağırlıkları toplamıyla orantısal olasılıkla seçilmektedir.

Analizimizi olasılıksal seçim kurulumunda yapıyoruz. Bu kurulumda, bir bireyin tekrarlanan seçimleri veya bir grubun seçimleri, her seçim kümesi üzerine bir olasılık ölçüsü atayan bir olasıllksal seçim kuralı ile özetlenir.

Doğan ve Yıldız (2018), tercih temelli bir dil kullanarak 'nedenlerin' oluşturulduğu, nedene dayalı bir seçim modeli sunan pro-con seçim modelini formüle etmekte ve analiz etmektedir. Doğan ve Yıldız (2018), zengin insan seçim davranışının her nüansının bu model aracilığıyla yakalanabileceğini göstermektedir. Yani, her olasillksal seçim fonksiyonu pro-con rasyoneldir.Böylesi bir sonuç için tabii bir endişe, pro-con seçim modelinde kullanılan sırlamaların sayısıdır. Pekçok seçim probleminde, problemle ilgili sıralamaların sayısı esasına sınırlıdır. Örneğin, klasik çekim etkisi senaryosunda, fiyat ve miktar gibi seçim için sadece iki ilgili kriter olduğu görülmektedir. Doğan ve Yıldız'dan (2018) alınan Örnek 1'de 
kullanılan lehte ve aleyhte tercihler bu kriterlere karşılık gelmektedir. Sonuç olarak, bir yem eklendiğinde bir alternatifin seçim olasılığı artabilir, çünkü bu alternatif ilgili bir kritere göre artık en kötü olmayabilir. Bu makalede, fiyat ve kalite gibi seçimle ilgili sadece iki gözlemlenebilir sıralamanın olduğu belirli bir seçim problemine odaklanıyoruz. Bu, bir çekim etkisi senaryosu sunan Örnek 1'in genelleştirilmesini sağlar. Analizimizde, gözlenen seçimlerin, verilen sıralama çiftinden elde edildiği bir model aracilığiyla üretilebileceğini garanti eden bir dizi seçim aksiyomu sunuyoruz. Bu karakterizasyonun dikkate değer bir yönü model ile çekim etkisi fenomeni arasındaki sıkı bağlantı1 gösteren çekim aksiyomu gibi bazı aksiyomlanı içeriği olmasıdır. Ayrıca, elde ettiğimiz sonuçların ve ispatlarındaki kurguların, modelin gözlemlenebilir veriden ampirik olarak belirlenmesinin önünü açtı̆̆ına inanıyoruz.

İncelenen özel pro-con seçim modeli, ikili kendilik modelleri üzerine literatürle ilgilidir. Bunlar arasında, De Clippel ve Eliaz (2012) bir ajanın mevcut alternatiflerin iki özelliğini temsil eden iki içsel benlik arasında bir uzlaşmaya varmaya çalıştı̆ı deterministik bir seçim modeli önermektedir. Bu bölümde yaptığımız gibi, iki iç benliği temsil eden iki düzenin de gözlemlenebilir olduğunu varsayıyorlar. Hem çekiciliğin deterministik formülasyonlarını hem de uzlaşma etkilerini açıklayan, iki benlik arasındaki pazarlık sorununa işbirlikçi bir çözümün sonucu olarak elde edilen nedene dayalı bir seçim modelini karakterize ederler. Bir diğer ilgili makale ise, iki tercihle olasılıksal fayda modelin karakterizasyonunu sağlayan Manzini ve Mariotti'dir (2018). Biz, burada tercihlerin gözlemlendiğini ve sadece olumlu yönde değil, olumsuz yönde de kullanıldığını varsayıyoruz. $\mathrm{Bu}$ nedenle, önemli ölçüde farklı bir karakterizasyonelde ediyoruz. Bu bağlamda, halen üzerinde çalıştığımı bir çalısmada analiz ettiğimiz ve daha karmaşık bir teknik yaklaşım gerektiren bir soru bireyin gözlemlenen seçimlerinden $\left(>_{1},>_{2}\right)$ sıralamalarını türetip türetemeyeceğimizdir. 